\title{
PELATIHAN PEMBUATAN ABON TONGKOL DI DESA GALIRAN SEMARAPURA KELOD KABUPATEN KLUNGKUNG BALI
}

\author{
P. Kusumaningsih ${ }^{1}$, D. W. Retnoningtyas ${ }^{2}$
}

\begin{abstract}
ABSTRAK
Abon merupakan salah satu teknik pengolahan makanan untuk memperpanjang masa penyimpanan ikan. Bahan yang digunakan sebagai bahan pembuatan abon pada pengabdian ini menggunakan bahan pangan lokal yang mudah ditemukan di Kabupaten Klungkung yaitu pindang tongkol dan bonggol pisang. Kedua bahan tersebut sering diolah oleh staf rumah singgah sebagai menu anak-anak asuh seperti pepes dan tum tetapi belum pernah diolah menjadi abon. Penambahan bonggol pisang pada abon pindang tongkol dapat menambah nilai gizi dari abon tersebut khususnya sumber karbohidrat dan serat, selain sumber protein dari pindang tongkol. Pelaksanaan pelatihan pengolahan abon langsung dipraktekkan oleh anak-anak asuh, dan hasilnya mereka pakai sebagai menu makanan. Ketrampilan mengolah bahan lokal ini baik bagi penyediaan nutrisi dan bekal ketrampilan untuk kedepannya bisa dikembangkan sebagai usaha di Rumah Singgah Budi Suci Dana.
\end{abstract}

Kata kunci : abon, pindang tongkol, bonggol pisang, nutrisi.

\begin{abstract}
Shredded fish is one of food technology, used to make the shelf-life of fish longer. The substances to make shredded fish are from local resources like mackerel tuna brine salting and banana weevil. These substances are low prices, easy to get in Klungkung residence and contain with good nutrition's. The staff in orphanage house usually cooked it into "pepes" and "tum". Banana weevil never used in shredded fish. Substitution of banana weevil can increase the value of the nutrition, mainly in carbohydrate and fiber beside protein. The implementation to process shredded fish had done by the orphanage and the taste was delicious and they used for dinner, breakfast on next day and provision meal in school. This skill is useful in developing entrepreneurship in Budi Suci Dana orphanage house in the future.
\end{abstract}

Keywords: shredded fish, mackerel tuna brine salting, banana weevil, nutrition.

\section{PENDAHULUAN}

Rumah Singgah Budi Suci Dana berlokasi di jalan Kenyeri, Desa Galiran Semarapura Kelod, di rumah singgah ini terdapat anak asuh berjumlah 22 orang dengan rentang umur 8 bulan sampai 16 tahun. Rumah singgah ini didirikan dan dipimpin oleh Pendeta I Kadek Agustono Daud putra daerah Klungkung yang berasal dari Desa Dawan dan Ibu Yohana Ratna Widyaningrum. Anakanak asuh di rumah singgah ini berlatar belakang keluarga tidak mampu, yatim, piatu ataupun yatim piatu, berasal dari berbagai daerah di Indonesia seperti Sumatra, Sulawesi, Sumba termasuk anak-anak yang berasal dari Bali. Anak-anak asuh ini dibawah pengawasan staf pengasuh sebanyak 3 orang yang berdomisili di Klungkung. Staf pengasuh di rumah singgah ini juga merupakan mantan anak-anak asuh dari Panti asuhan atau sekarang disebut Lembaga Kesejahteraan Sosial Anak, oleh karena itu mereka dapat memahami kondisi anak-anak asuh yang dirawat dan permasalahan yang sering dihadapi oleh anak-anak tersebut.

\footnotetext{
${ }^{1}$ Dosen PS Ilmu Gizi, FIKST UNDHIRA, Badung, purwak.05@undhirabali.ac.id.

${ }^{2}$ Dosen PS Psikologi, FIKST UNDHIRA, Badung
} 
Permasalahan yang dihadapi di rumah singgah adalah bagaimana cara mendapatkan sumber protein yang dapat diperoleh dengan mudah dengan harga yang terjangkau serta dapat ditambahkan ke dalam varian menu makanan bagi anak-anak asuh. Inovasi dan diversifikasi pangan dengan memanfaatkan bahan pangan lokal sebagai bahan pangan alternatif dapat menjawab permasalahan diatas (Adisanjaya, 2018; Saragih, 2018). Kabupaten Klungkung memiliki produk hasil perikanan pindang tongkol yang dapat dijadikan sumber protein alternatif selain daging sapi atau ayam. Umbi-umbian seperti bonggol pisang dapat dijadikan sumber protein dan serat alternatif. Kandungan protein pindang dan bonggol cukup baik, yaitu 27\% dan $34 \%$ sedangkan kandungan serat dari bonggol 29,6\% (Elisabeth, 2013; Estu, 2015). Keunggulan keduanya merupakan bahan pangan yang mudah diperoleh dengan harga yang relatif murah dan bebas lemak. Pengolahan pindang menjadi abon merupakan salah satu alternatif pengolahan yang dapat dipilih untuk meningkatkan cita rasa dan memperpanjang daya simpan (Handoko, et. al., 2015). Penambahan bonggol pisang sebagai bahan substitusi pada pembuatan nugget ayam diketahui dapat meningkatkan kandungan protein dan serat (Muliani et. al., 2018). Berdasarkan hasil penelitian tersebut, dengan ditambahkannya bonggol pisang kedalam abon pindang dapat meningkatkan kandungan gizi pada abon.

Pindang tongkol di Rumah Singgah Budi Suci Dana, biasanya diolah menjadi pepes, semur kecap, pindang bumbu merah dan bumbu kuning dan bonggol pisang hanya diolah sebatas menjadi 'tum'. Abon pindang yang dicampur dengan bonggol pisang sebagai bahan substitusi belum pernah diolah menjadi varian menu di rumah singgah Budi Suci Dana.

Penerapan higienitas diperkenalkan saat melakukan pengolahan pindang menjadi abon seperti pemilihan pindang yang masih baik. Pencucian bumbu-bumbu dapur sebelum diolah dan kebersihan dapur tempat memasak serta alat-alat yang akan digunakan untuk memasak. Cara menyajikan abon yang akan disantap ataupun disimpan, ditempatkan di wadah tertutup agar tidak ada serangga penyebar penyakit yang dapat mencemari abon. Kebersihan dari orang yang akan memasak dengan mencuci tangan terlebih dahulu. Tindakan ini dilakukan untuk mencegah terjadinya keracunan makanan karena pengolahan yang tidak higienis dan toksik yang ditularkan dari bakteri yang terdapat pada pindang, bumbu-bumbu, lingkungan dapur dan alatalat masak dan penyajian yang digunakan (Yulia, 2016).

Pelatihan pengolahan makanan sehat berbahan pangan lokal, penyuluhan gizi dari bahan pangan lokal dan pendidikan dalam memilih makanan sehat bagi anak-anak belum pernah menjangkau di rumah singgah Budi Suci Dana. Pengetahuan dan keterampilan tentang pemanfaatan bahan pangan lokal dengan mengolah pindang tongkol menjadi abon dengan bahan substitusi bonggol pisang sebagai sumber protein dan serat alternatif diharapkan bisa memberikan wawasan baru bagi anak-anak asuh dan staf pengasuh tentang pemahaman makanan bergizi, bahwa pindang dan bonggol pisang merupakan panganan bergizi murah meriah, serta mendukung ketahanan pangan, dan kedepannya bisa menjadi dasar kewirausahaan yang dapat mendukung rumah singgah dan bagi anak-anak asuh yang bisa dikembangkan berwirausaha sendiri setelah lulus dari asuhan.

Permasalahan lainnya yang dihadapi adalah anak-anak masih belum memahami untuk memilih makanan sehat diluar lingkungan rumah singgah. Jajanan yang dibeli masih berupa makanan yang kandungan nutrisinya kurang baik bagi kesehatan jika terlalu sering dikonsumsi. Penanaman tentang pengertian apa itu makanan sehat dan pemahaman mengapa lebih baik memilih makanan sehat serta dampaknya bagi kesehatan tubuh, perkembangan fisik dan mental, perlu dilakukan pembelajaran dan pengenalan sejak usia dini melalui pendekatan psikologi nutrisi (Ogden, 2010). Edukasi tentang nutrisi dengan memberikan contoh-contoh nyata objek yang mengandung nutrisi dan menunjukkan secara visual dampaknya didalam tubuh, akan menanamkan memori dan kesadaran bagi anak-anak akan pentingnya mengkonsumsi makanan yang sehat (Baskale, 2009; Gripshover and Ellen, 2014). Pembelajaran tentang teori nutrisi yang diberikan disesuaikan dengan perkembangan kognitif berdasarkan umur, sehingga dapat memberikan solusi dalam mengarahkan anak-anak asuh di Rumah Singgah Budi Suci Dana kepada perubahan pola prilaku positif. 


\section{METODE PELAKSANAAN}

Metode yang digunakan dalam pelaksanaan pengabdian pengolahan abon adalah sebagai berikut: (1) penyuluhan tentang hygiene sanitasi dalam mengolah makanan, (2) penyuluhan pemahaman ketahan pangan dalam memanfaatkan sumber daya alam lokal bagi penyediaan makanan yang bernutrisi, (3) penyuluhan mengenai nutrisi yang terkandung didalam ikan, (4) Pembelajaran cara memilih makanan sehat yang baik untuk tubuh, (5) pelatihan mengolah pindang tongkol dan bonggol menjadi abon, mulai dari pengenalan bumbu, tahapan membuat abon, kebersihan bahan, alat dan sanitasi personal, hingga praktek membuat abon oleh anakanak asuh. Penyuluhan dan praktek pengolahan abon dilakukan oleh Dosen, mahasiswa Program Studi Ilmu Gizi, dosen psikologi serta narasumber yang berkompeten dibidang kuliner.

\section{HASIL DAN PEMBAHASAN}

Pelaksanaan pengabdian kepada staf dan anak-anak asuh di Rumah Singgah Budi Suci Dana dimulai dengan memberikan sosialisasi kegiatan yang akan dilaksanakan dan materi serta praktek pelatihan yang akan diberikan kepada staf dan anak-anak asuh. Aktifitas pelaksanaan pengabdian dapat dilihat pada Gambar 1 dan Gambar 2.

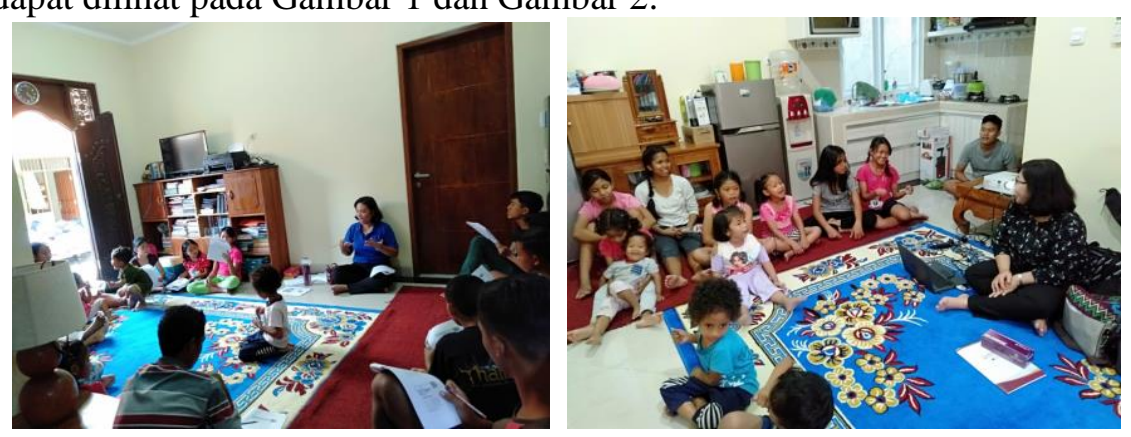

Gambar 1. Penyuluhan dan pembelajaran kepada anak-anak asuh

Penyuluhan, pembelajaran serta pelatihan pada pengabdian ini dilaksanakan oleh dosen, mahasiswa dan narasumber yang berkompeten di bidang pangan, gizi, psikologi dan tata boga. Anak-anak asuh beserta staf sangat antusias dalam mengikuti setiap sesi penyuluhan dan pembelajaran yang dilaksanankan. Peningkatan pengetahuan tentang hygiene sanitasi, ketahanan pangan, nutrisi pada ikan dan pembelajaran pentingnya memilih makanan sehat dapat dilihat dari hasil kenaikan pre dan post-test yang telah dilakukan. Rata-rata anak-anak asuh di rumah singgah berpendidikan mulai dari SD hingga SMA dan memiliki keingintahuan yang besar tentang masalah kesehatan, gizi dan ketrampilan memasak sesuai dengan cita-cita yang ingin mereka wujudkan sebagai ahli gizi, psikologi, olahragawan, dokter dan wirausaha.

Tabel 1. Skor pre dan post-test materi pengabdian

\begin{tabular}{|llccc|}
\hline No & \multicolumn{1}{c}{ Materi } & \multicolumn{1}{c}{$\begin{array}{l}\text { Rerata Skor Pre- } \\
\text { Test }\end{array}$} & $\begin{array}{l}\text { Rerata Skor } \\
\text { Post-Test }\end{array}$ & $\begin{array}{l}\text { Presentase } \\
\text { Peningkatan (\%) }\end{array}$ \\
\hline 1. & Higiene Sanitasi Makanan & 67.31 & 81.31 & 27.31 \\
\hline 2. & Ketahanan Pangan & 77.69 & 93.07 & 29 \\
\hline 3. & Nutrisi pada Ikan & 76.31 & 93.62 & 24.79 \\
\hline 4. & Pemilihan Makan Sehat & 30.76 & 50.76 & 65.23 \\
\hline
\end{tabular}

Peningkatan pengetahuan ini dapat dilihat dari hasil analisa skor pre dan post-test. pada pemahaman hygiene sanitasi diperoleh rata-rata pre-test adalah 67.31 dan post-test adalah 81.31. Presentase peningkatannya sebesar $27.31 \%$. Hasil pre-test ketahanan pangan adalah 77.69 dan post-test 93.07 dan presentase kenaikannya sebesar 29\%. Pengetahuan tentang nutrisi pada ikan hasil pre-testnya 76.31 dan post-test 93.62, presentase peningkatannya sebesar $24.79 \%$. Terakhir hasil pre-test dalam memilih makan sehat pre-testnya sebesar 30.76 dan posttestnya sebesar 50.75. Presentase kenaikannya adalah 65.23\%. Hal ini menunjukkan bahwa 
terjadi peningkatan pemahaman dan pengetahuan dari anak-anak asuh terhadap materi dan pembelajaran yang disampaikan. Kenaikan yang diperoleh dalam hasil test menunjukkan materi yang diberikan mampu diserap dan dipahami oleh anak-anak. Skor pre dan post-test peserta dapat dilihat pada Tabel 1. Pelatihan secara langsung tentang pengenalan bahan-bahan yang akan digunakan dalam resep abon dan tahap-tahap pengolahan cepat dimengerti dan dengan lancar dipraktekkan oleh anak-anak, dengan pengawasan dari tim pengabdian.

Hasil abon yang dibuat sendiri oleh anak-anak memiliki citarasa yang enak dan disukai oleh anak-anak. Abon yang telah jadi langsung dipakai mereka sebagai menu makan malam dan dapat disimpan untuk sarapan keesokan hari dan bekal ke sekolah.
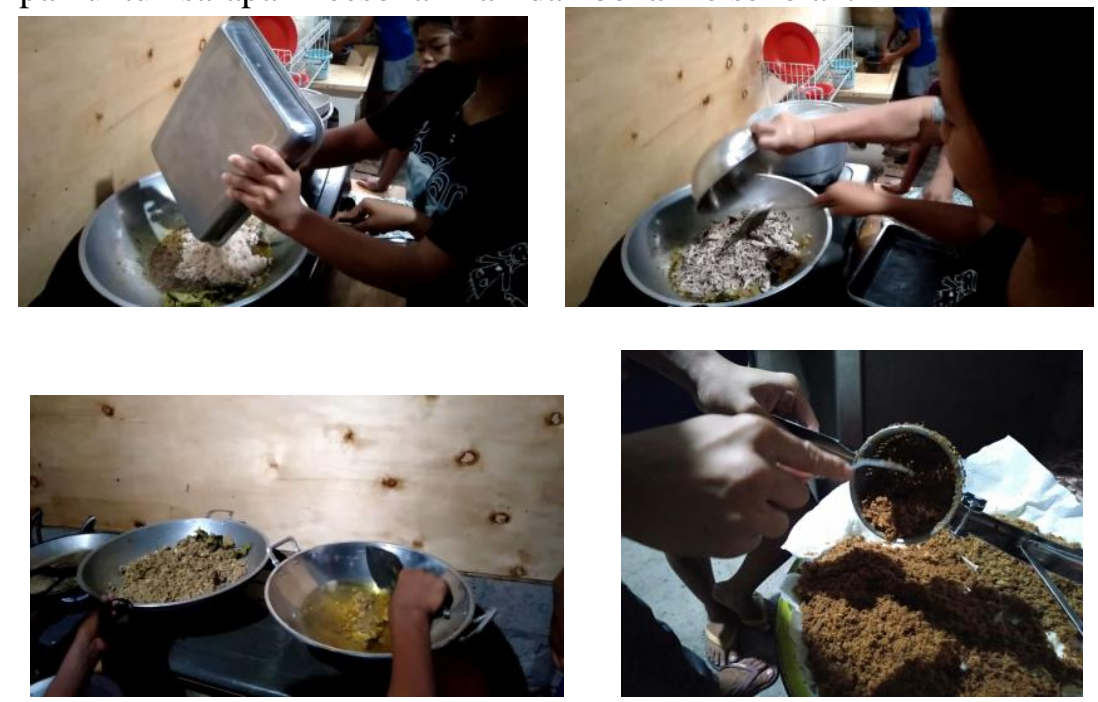

Gambar 2. Tahapan pengolahan abon pindang tonhkol dan bonggol pisang

\section{KESIMPULAN}

Pelaksanaan pengabdian ini telah dapat dilaksanakan dengan lancer tanpa kendala yang berarti. Materi yang disampaikan oleh narasumber dapat dengan mudah dipahami oleh anak-anak asuh dilihat dari kenaikan presentase hasil pre-dan post-test. Anak-anak mampu memahami memanfaatkan sumber daya alam lokal untuk memenuhi nutrisi yang dibutuhkan oleh tubuh dengan harga terjangkau, disekitar lingkungan mereka.

Praktek pengolahan abon sangat baik dilaksanakan oleh anak-anak baik yang wanita dan pria dengan memperhatikan teknik pengolahan dan tahapan yang telah dijelaskan sehingga dihasilkan abon pindang tongkol dan bonggol pisang yang lezat, bersih, bernutrisi dan memiliki manfaat untuk menu makan malam, sarapan dan bekal ke sekolah.

\section{UCAPAN TERIMA KASIH}

Ucapan terimakasih disampaikan kepada Rektor Universitas Dhyana Pura melalui Ketua LP2M Universitas Dhyana Pura yang telah mendanai melalui habiah internal PT sehingga pengabdian ini dapat terlaksana dengan baik. Kami juga mengucapkan terimakasih kepada Pimpinan Rumah Singgah Budi Suci Dana di Kabupaten Klungkung beserta para staf dan anak-anak asuh yang telah meyediakan tempat dan perhatiannya untuk pelaksanaan pelatihan pengolahan abon. Penulis juga sangat berterimakasih kepada semua tim pengabdian atas sumbangsih tenaga dan keilmuannya dalam mendukung terwujudnya pengabdian ini. 


\section{DAFTAR PUSTAKA}

Adisanjaya, NN. 2018. Potensi, Produksi Sumberdaya Ikan di Perairan Laut Indonesia dan Permasalahnya. http://www.eafm-indonesia.net/public/files/penelitian/5ae09. Accessed April 24, 2018.

Baskale, H.; Z., Zulhal, B., Gunsel, B., and Meziyet, A. 2009. Use of Piaget's theory in preschool nutrition education. Rev. Nutr., Campinas, 22(6):905-917, Nov./Dec.

Elisabeth, D. A. A. 2013. Kerupuk Bonggol Pisang: Dari Limbah Yang Kaya Gizi Ke Meja Makan Kita. Sinartani: Agroinovasi. Edisi 24-30 April 2013 No.3504 Tahun XLIII.

Estu, R. I. S. 2015. Identifikasi Bakteri Pada Pindang Tongkol (Euthynnus Affinis) Produksi Weleri, Jawa Tengah Dan Pindang Tongkol Yang Direndam Ekstrak Rempah (Jahe, Lengkuas, Kunyit, Dan Kluwak) Sebagai Pengawet Alami. http://repository.unika.ac.id/48/.

Gripshover, S. J. and Ellen, M. M. 2014. Teaching Young Children a Theory of Nutrition: Conceptual Change and the Potential for Increased Vegetable Consumption. Psychological Science 24(8): 1541-1553.

Hardoko, P. Y. Sari and Y. E. Puspitasari. 2015. Subtitusi Jantung Pisang Dalam Pembuatan Abon dari Pindang Ikan Tongkol. Jurnal Perikananan Dan Kelautan. ISSN: 0853-7607.

Muliani, A., Ernawati, N. dan Etty, S. 2018. Pengaruh Penambahan Bonggol Pisang Terhadap Daya Terima dan Kandungan Gizi Nugget Ayam. Skripsi. Fakultas Kesehatan Masyarakat. Universitas Sumatera Utara.

Ogden, J. 2010. The Psychology of Eating, From Healthy to Disordered Behavior. Second Edition. United Kingdom: Blackwell Publishing.

Saragih, B. dan K., Dolu. 2018. Pemanfaatan Tepung Bonggol Pisang (Musa paradisiaca linn) Sebagai Pangan Alternatif Dalam Mendukung Ketahanan Pangan. www.researchgate.com.

Yulia. 2016. Higiene Sanitasi Makanan, Minuman Dan Sarana Sanitasi Terhadap Angka Kuman Peralatan Makan Dan Minum Pada Kantin. Jurnal Vokasi Kesehatan. Vol. II, No. 1, hlm. 55-61. 